\title{
Phase Change Material Coating on Autoclaved Aerated Lightweight Concrete for Cooling Load Reduction
}

\author{
Chantana PUNLEK, Somchai MANEEWAN, Atthakorn THONGTHA * \\ Department of Physics, Faculty of Science, Naresuan University, Phitsanulok, Thailand, 65000 \\ cross $^{\text {ref }}$ http://dx.doi.org/10.5755/j01.ms.23.2.15451
}

Received 15 August 2016; accepted 05 September 2016

\begin{abstract}
This work is focused on enhancing the thermal effectiveness of autoclaved aerated concrete (AAC) by the application of phase change material (PCM) as a coating. The dynamics of heat transfer and the cooling load of air conditioning system in the two tested houses with different wall materials (AAC and AAC with PCM coating) were investigated. The work demonstrated that by coating phase change material onto the exterior surface of the building materials a significant increase in the thermal effectiveness of the building materials was achieved and determined by comparing the lower interior surface temperature, heat flux evolution and room temperature. The increase in thermal effectiveness was applied to the AAC. It was demonstrated that the cooling load and power consumption of air conditioning system in buildings using the wall-PCM coating combination can be reduced variously by about $25 \%$.

Keywords: light weight concrete, phase change material coating, temperature fluctuation, energy saving.
\end{abstract}

\section{INTRODUCTION}

City buildings and offices and residential housing are the largest electricity consumers in modern cities, and building owners and occupiers pay a high price for their power consumption. A decrease in energy dependence of buildings is one of the keys to reducing the amount and cost of energy consumption, and is now required and being demanded in the development of new and sophisticated building designs. New materials and construction systems must therefore contribute to meet power reduction requirements and thereby promote both energy conservation in construction and economic sustainability in energy generation.

One of the approaches to reducing energy consumption in buildings and enhancing the indoor thermal environment is the integration of phase change material (PCM) into a building or building services system, which was first used for thermal storage in buildings in 1980 [1], to increase thermal storage effectiveness. Then, experiments have been reported that used PCMs in PCM trombe walls [2, 3], wall boards [4-6], shutters or window [7], ceiling boards [8,9] and roof [10-12].

Approximately 2.6 billion tons of cement, is mostly used for making concrete, is annually produced around the world. Concretes were divided into two major types: mineral concrete and polymer concrete [13-14]. In Thailand, around $28.000 .000 \mathrm{~m}^{2}$ Autoclaved Aerated Concrete (AAC) was used in 2012. Its popularity was due to it being the only type of wall material which exhibits the ability to meet building energy saving requests of about $50 \%$ without adding other affiliated thermal insulation materials [15]. Of further importance, AAC is lightweight and has a highly porous structure (Approximately $80 \%$ of the volume of the hardened material is made up of pores, $50 \%$ being air pores and $30 \%$ being micropores), a lower

\footnotetext{
* Corresponding author. Tel.: +66 559 63550; fax: +66 55963501 .

E-mail address: atthakornt@nu.ac.th (A. Thongtha)
}

thermal conductivity, a higher heat resistance, a lower shrinkage, and an easier and faster construction process than traditional concrete [16-18].

To enhance sufficiently the thermal properties of $\mathrm{AAC}$, the integration of phase change material (PCM) into AAC wall material was considered to reduce the heat flux from the outer wall to the inner wall, leading to the achievement of energy conservation goals in buildings. In this current work, the thermal effectiveness of the AAC is therefore investigated by the application of PCM as a coating on the exterior surface of AAC. This was compared with the PCM uncoated AAC material. The dynamics of heat transfer and cooling load of air conditioning system in the two experimental houses were also investigated and compared.

\section{EXPERIMENTAL METHODOLOGY}

\subsection{Application of PCM}

In AAC preparation, the raw materials of fine sand (Approximately $0.5 \mathrm{~kg} / \mathrm{m}^{2}$ of phase change material (PCM) was applied as a coating on the external surface of the autoclaved aerated concrete with a uniform area of $20 \mathrm{~cm}$ wide $\times 60 \mathrm{~cm}$ long as shown in Fig. 1 . AAC with PCM-coated surface was then used to construct a tested house.

\subsection{House model design}

The thermal effectiveness performance of the two small houses was tested. Each house was $13.25 \mathrm{~m}^{3}$ in volume, and was built as shown in Fig. 2. These houses were constructed using the AAC and AAC with coated PCM wall materials. Each house has 4 sides, each composed of walls of $5.52 \mathrm{~m}^{2}$ area and $8 \mathrm{~cm}$ thickness with coating cement plaster and no painting of either internal or external surfaces. The roofs of the four houses used CPAC Monier with aluminum foil to reflect heat. The inclination of the roof angle was $30^{\circ}$ to the horizontal plane. The 
ceiling of each house was made of gypsum board with thickness of $1 \mathrm{~cm}$ for preventing and reducing the transmitted heat through the roof. A wooden door $0.84 \mathrm{~m} \times 1.84 \mathrm{~m}$ in size was set up in the south side of each house. A frame of window glass $0.72 \mathrm{~m}$ wide $\times 1.0 \mathrm{~m}$ long was set up in the west side of each house.

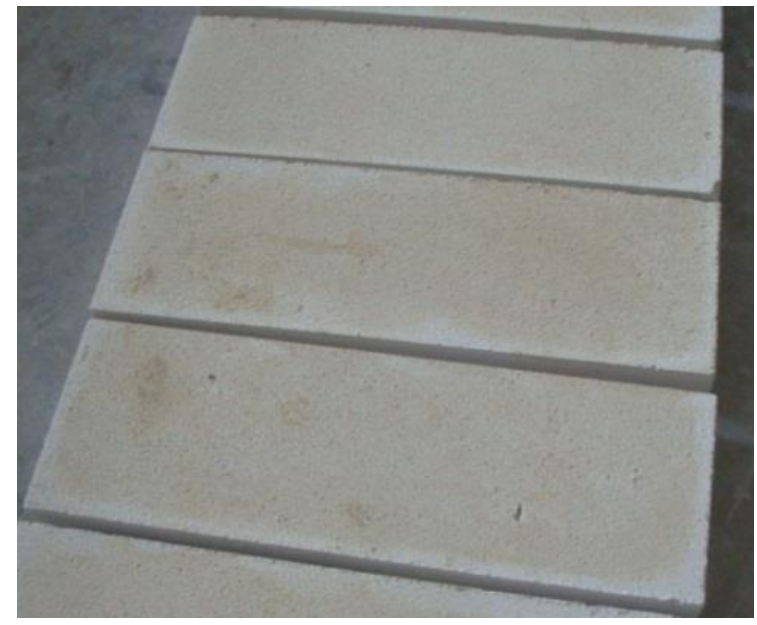

Fig. 1. The autoclaved aerated concrete with coated phase change material

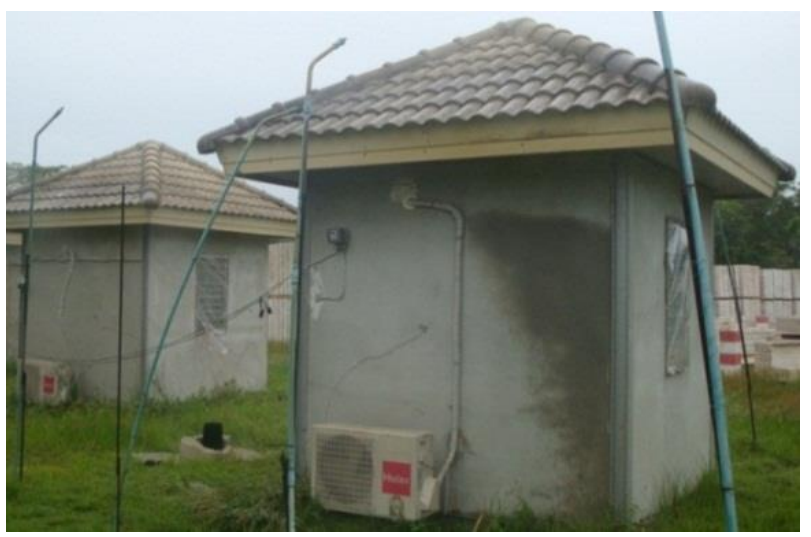

Fig. 2. View of the tested houses with the AAC and AAC with coated PCM wall materials

\subsection{Air temperature measurements}

Both houses also had an operating air conditioner with cooling capacity of 9,487.41 Btu/h. Fig. 3 exhibits these designs. K-type thermocouples with accuracy of $\pm 0.5^{\circ} \mathrm{C}$ were employed to measure temperatures. They were attached to the exterior and interior wall surfaces on 4 sides by the thermocouples in close contact with the wall surface and insulated using aluminum foil tape. Thermal paste was applied to ensure good thermal contact between the thermocouples and the surfaces. Ambient temperature and room temperature of each house were measured by suspending the thermocouple in a shaded area alongside and inside houses as also shown in Fig. 3. The solar radiation intensity incident on a horizontal plane was measured using a Kipp-and-Zonen solarimeter (accuracy $\pm 2 \%$ ). The wind speed throughout the duration of the investigation was measured using a wind anemometer. All data were recorded at 5 min intervals using a data logger. Data was recorded continuously over $24 \mathrm{~h}$ in real ambient condition. Further, the cooling load of air conditioner was tested continuously over $24 \mathrm{~h}$ with closed the window and the door in each house. The whole experimental system of cooling load was kept constantly at around $25^{\circ} \mathrm{C}$ by the air conditioner.

\section{RESULTS AND DISCUSSION}

\subsection{Tested houses results}

Fig. 4 shows the result from the test houses each with different wall types that measured concurrently. The exterior and interior surface temperature evolution, and room temperature of the two houses with no air conditioning were investigated and compared, and subsequent tests were done with the air conditioning operative.

\subsection{Interior surface temperature evolution of house wall}

The fluctuations in solar radiation, ambient temperature and interior surface temperature evolution of house wall in each side are shown in Fig. 4. These tests were done and results observed from 6 am of day to 6 am of the following day, giving a $24 \mathrm{~h}$ test cycle. The fluctuating nature of solar radiation in the tropic occurs because of periodical cloud cover which is typical between sunrise $(6.00 \mathrm{am})$ and sunset $(7.00 \mathrm{pm})$ with the highest values of approximately $1.05 \mathrm{~kW} / \mathrm{m}^{2}$ around midday. Wind velocity at the test site was between 0.20 and $3.54 \mathrm{~m} / \mathrm{s}$. The ambient temperature depended upon weather conditions. The ambient temperature fluctuated between $\sim 26^{\circ} \mathrm{C}$ in the morning between $5-6$ am and up the maximum value of $\sim 36{ }^{\circ} \mathrm{C}$ at around $4 \mathrm{pm}$.

Considering the AAC house, the temperature evolutions of the interior surfaces of each side in AAC house are illustrated as Fig. 4. The maximum interior wall temperature of the north, south, east and west side surfaces reached as high as approximately $37.0^{\circ} \mathrm{C}, 38.5^{\circ} \mathrm{C}, 38.5^{\circ} \mathrm{C}$ and $38.5{ }^{\circ} \mathrm{C}$ at around the same time of $5 \mathrm{pm}$.

For the PCM-coated AAC house, the temperature evolutions of the interior surfaces of each side in PCMcoated AAC house are also shown as Fig. 4. The maximum interior wall temperature of the north, south, east and west side surfaces peaked as high as approximately $36.0^{\circ} \mathrm{C}$, $37.0^{\circ} \mathrm{C}, 36.5^{\circ} \mathrm{C}$ and $37.0^{\circ} \mathrm{C}$ at around the same time of $5.30 \mathrm{pm}$.

This is observed that the PCM-coated walls temperature fluctuations of each aspect are lower than for the ordinary AAC walls; the evolutions of the north, south, east and west side interior wall temperatures being similar. The temperature evolution curves between coated and uncoated-PCM walls have a phase difference of approximately $30 \mathrm{~min}$. Therefore, this is presumed that PCM coating on the exterior surface of AAC material increases the inertia to the ordinary AAC wall. Concerning the north aspect wall temperature curve, the PCM coated AAC material causes a reduction of the temperature amplitude of about $1.0^{\circ} \mathrm{C}$. For the south and west wall temperature curve, this decline of the amplitude is about $1.5^{\circ} \mathrm{C}$. For the east wall temperature curve, the decrease of the amplitude is about $2.0^{\circ} \mathrm{C}$. 


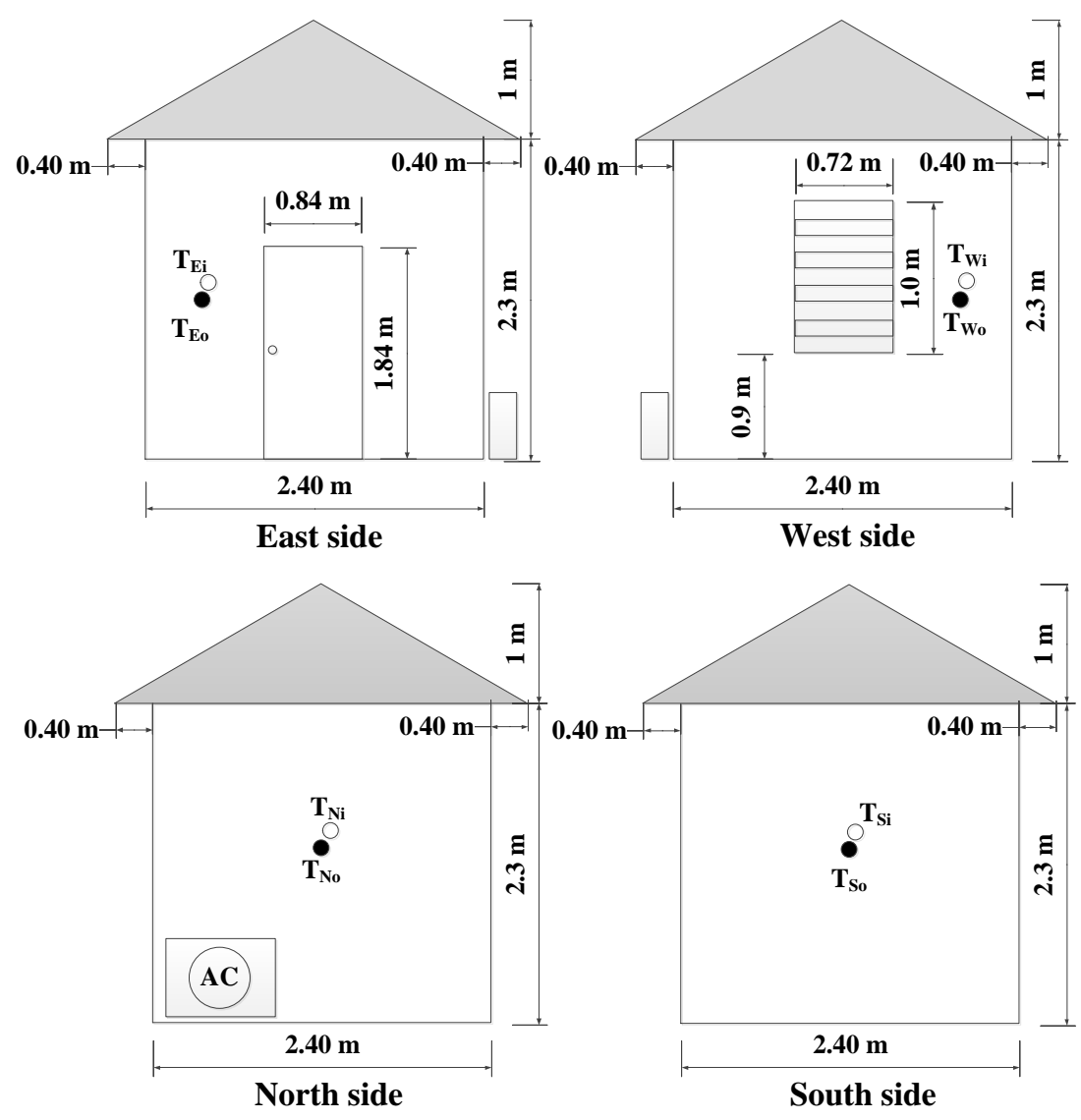

Fig. 3. Dimensions of the tested houses and setting positions of the thermocouple lines of the two houses

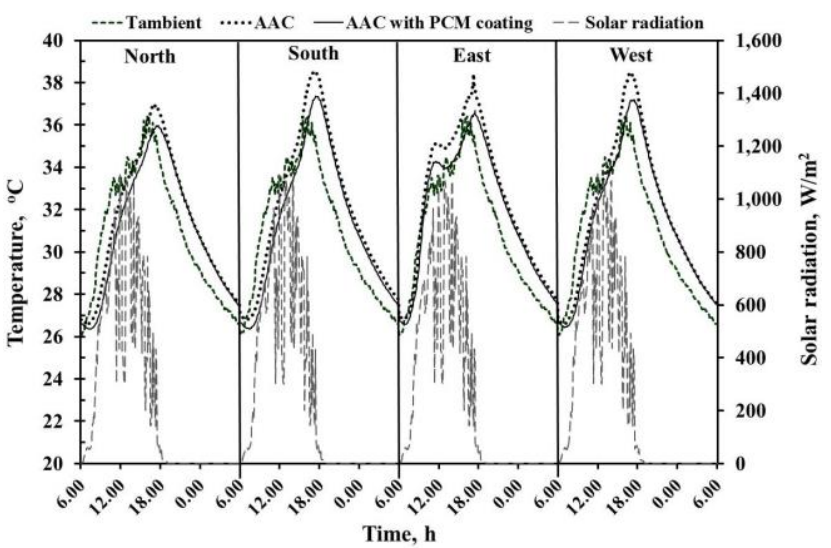

Fig. 4. Comparison of inner wall temperatures of the two houses

\subsection{Comparison of flux evolution}

Heat fluxes on both the interior and exterior surfaces of the walls of the two houses were investigated, as illustrated in Fig. 5. Heat flux on the wall surface is positive when the heat wave propagates from the outer surface to the inner surface (That is, when the exterior surface temperature is higher than the interior surface temperature) while heat flux on the wall surface is negative when heat wave propagates from the inside surface to the outside surface (Exterior surface temperature is less than interior surface temperature).

With the heat fluxes of the AAC house wall, positive heat fluxes in all of the north, south, east and west surfaces were first increased and reached its maximum value of approximately $8.0,21.5,35.0$ and $22.0 \mathrm{~W} / \mathrm{m}^{2}$ at around $11 \mathrm{am}, 4 \mathrm{pm}, 9.30 \mathrm{am}$ and $4 \mathrm{pm}$ the north, south, east and west surfaces respectively and then dropped in value over time passed after each those times. It was found that the negative heat fluxes of the north, south, east and west surfaces began at around $4.30 \mathrm{pm}, 6 \mathrm{pm}, 5 \mathrm{pm}$ and $5.30 \mathrm{pm}$, respectively. The highest value of the heat fluxes was about $5.0,4.0,4.5$ and $5.0 \mathrm{~W} / \mathrm{m}^{2}$ at around $7.30 \mathrm{pm}$, $8.30 \mathrm{pm}, 7.30 \mathrm{pm}$ and $7.30 \mathrm{pm}$ for the north, south, east and west surfaces respectively, then dropped for day time below these values.

For the heat fluxes of AAC with PCM house wall, the maximum positive value in the part of the north, south, east and west surfaces was observed at about 4.5, 16.0, 28.0 and $17.0 \mathrm{~W} / \mathrm{m}^{2}$ at around $11 \mathrm{am}, 4 \mathrm{pm}, 9.30 \mathrm{am}$ and $4 \mathrm{pm}$, respectively. The maximum negative value for each of the north, south, east and west surfaces was observed at about 5.0, 4.0, 4.5 and $4.5 \mathrm{~W} / \mathrm{m}^{2}$ at around $7.30 \mathrm{pm}$, $8.30 \mathrm{pm}, 7 \mathrm{pm}$ and $7.30 \mathrm{pm}$, respectively. This shows that the maximum positive heat flux of the PCM coated AAC house wall in all sides had less than positive heat flux value of AAC house wall. The maximum positive heat flux of the PCM coated AAC wall on each of the north, south, east and west surfaces was less than that of the uncoated AAC wall of around 3.5, 5.5, 7.0 and $5.0 \mathrm{~W} / \mathrm{m}^{2}$, respectively. This demonstrates that the utilization of PCM on the exterior surfaces of a building using Autoclaved Aerated Concrete (AAC) can reduce the heat transfer through the building envelop and lead to an improvement in the insulative efficiency of buildings. Using cooling load 
and power consumption measurements, this improvement was up to nearly a $30 \%$ reduction in cooling load and power consumption. This is clearly a significant result.

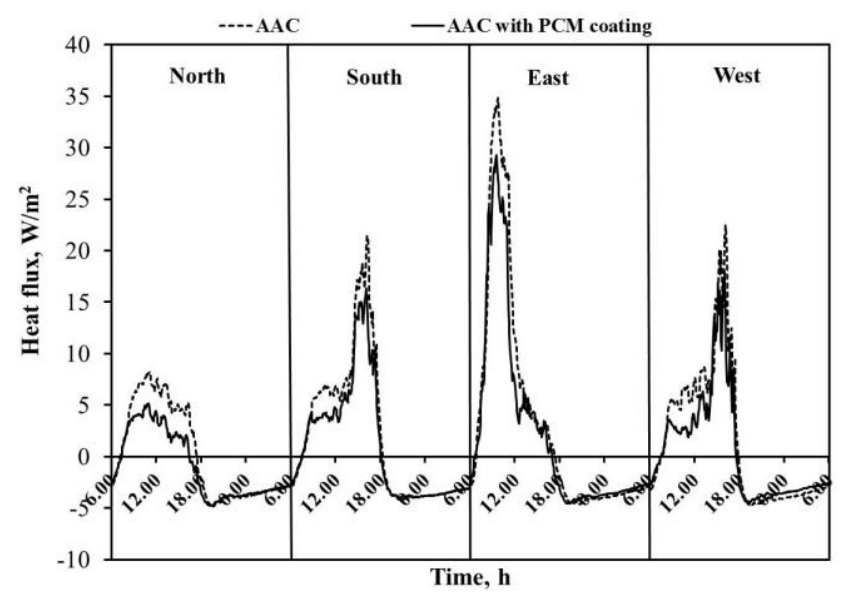

Fig. 5. Comparison of heat flux evolution of the two houses

\subsection{Comparison of room temperature}

Room temperatures in the two houses between 6 am of day and 6 am of the following day are shown in Fig. 6. The effect of the fluctuating nature of solar radiation, ambient temperature, and exterior and interior surface temperature evolution of the house walls on each side on the room temperature of each house varied over the period of the day. It can be seen that the room temperature of the two houses was approximately equal between the times of 6 am and $11.30 \mathrm{am}$. After that time, different peak temperatures were reached in each test house at different times.

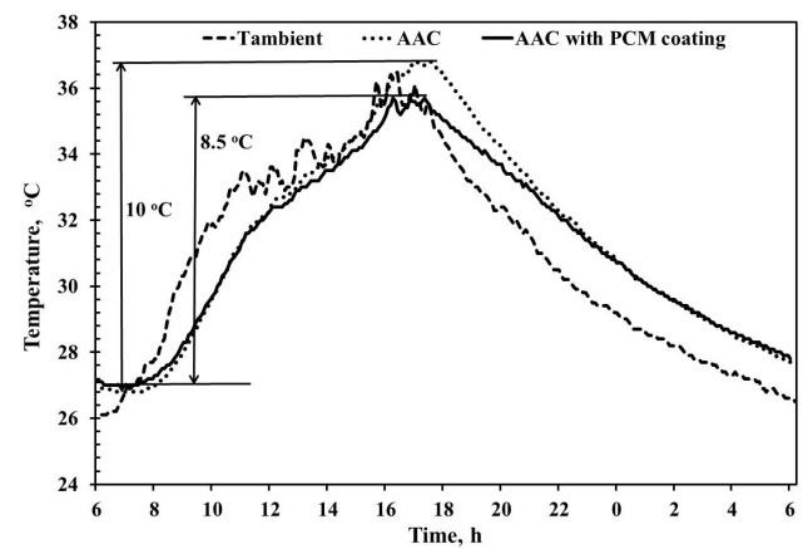

Fig. 6. Comparison of room temperature of the two houses

After 11.40 am the temperature readings diverged. The room temperature of the AAC house rose more rapidly, and achieved the highest peak value of around $37^{\circ} \mathrm{C}$ at about $5 \mathrm{pm}$. The room temperature of the PCM coated house peaked at $35.5^{\circ} \mathrm{C}$ at about $5 \mathrm{pm}$. The PCM utilization enables to maintain the room temperature within the comfort zone by decreasing the maximum room temperature to a maximum value of $1.5^{\circ} \mathrm{C}$. This indicates the use of AAC with PCM coating significantly reduces the daily room temperature fluctuation of partitions. The daily room temperature swing was reduced from $10{ }^{\circ} \mathrm{C}$ in AAC house to only $8.5^{\circ} \mathrm{C}$ in the PCM-coated house which causes from the thermal absorption of PCM-coated exterior surface wall. This leads to a reduction of heat transfer into the inner section of the PCM-coated house. This result corresponded to previous work [19-22].

When the ambient temperature was compared against the room temperatures of the two houses, it was found that room temperature of the AAC house was lower than the ambient temperature between 7 am and $2 \mathrm{pm}$; that is a $7 \mathrm{~h}$ period, while that of the PCM-coated AAC wall house was lower than ambient temperature between around 7 am and $4.30 \mathrm{pm}$; a $9 \mathrm{~h} 30 \mathrm{~min}$ period. This clearly demonstrated that the room temperature of PCM coated house was lower than the ambient temperature for $2 \mathrm{~h} 30$ min longer than that of the uncoated AAC house, which indicated the greater insulative efficiency of PCM coating.

\subsection{Comparison of cooling load}

The cooling load of the air conditioners in the two houses was measured and compared as shown in Fig. 7.

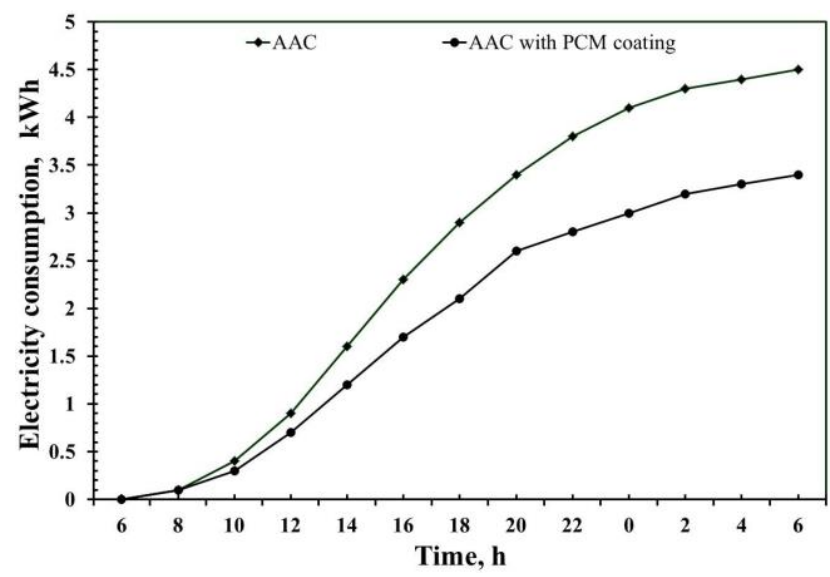

Fig. 7. Comparison of cooling load of air condition in the two houses

Both the houses were firstly tested with closed windows and doors for $24 \mathrm{~h}$ (from $6 \mathrm{am}$ to $6 \mathrm{am}$ ). It was found that the cooling load in the AAC wall house started to increase the quickest, and continued to increase over the $24 \mathrm{~h}$ (from $6 \mathrm{am}$ to $6 \mathrm{am}$ ). The cooling load on the air conditioner in this house was around $4.5 \mathrm{kWh}$ of electrical consumption. The cooling load in the PCM-coated AAC wall houses had a similar trend to the AAC wall house. At the end of the $24 \mathrm{~h}$ period, the cooling loads in the PCMcoated AAC wall houses were around $3.4 \mathrm{kWh}$ of electrical consumption. This is shown that the savings in electrical consumption PCM coated AAC house was lower than another house approximately $25 \%$. This result agrees with the similar mechanism for thermal efficient assessment of building envelopes, which heat transfer from outside part could be effectively absorbed, and affects to reducing the fluctuation of room temperature and lowering the peak of air conditioning load [19-22]. This confirms the ability of the phase change material to significantly reduce the cooling load and electrical consumption of air conditioning plants. Hence, autoclaved aerated concrete with PCM coating on the outside surface can be useful in building construction.

\section{CONCLUSIONS}

The use of phase change material for thermal storage on outer wall surfaces of buildings can reduce the heat 
wave propagation from the outer wall to the inner wall and therefore the interior room spaces. The cooling load on air conditioners in buildings with PCM coating on the exterior walls can save the electrical power consumption of approximately $25 \%$. The effectiveness of PCM coatings on the exterior surface of buildings has been clearly exhibited both in regard to thermal effectiveness, power consumption reduction and the resultant economic benefits. Therefore, it is suitable as an adjunct material to be applied concrete and masonry constructions in the future.

\section{Acknowledgements}

The authors would like to thank the Thailand Research Fund (TRF), Faculty of Science, Naresuan University and INSEE Superblock Company Limited for providing financial support to this research work, and our research center.

\section{References}

1. Sharma, A., Tyagi, V.V., Chen, C.R., Buddhi, D. Review on Thermal Energy Storage with Phase Change Materials and Applications Renewable \& Sustainable Energy Reviews 13 2009: pp. 318-345.

2. Kara, Y.A. Diurnal Performance Analysis of Phase Change Material Walls Applied Thermal Engineering 102 2016: pp. $1-8$.

3. Zhou, G.B., Pang, M.M. Experimental Investigations on Thermal Performance of Phase Change Material - Trombe Wall System Enhanced by Delta Winglet Vortex Generators Energy 93 2015: pp. 758-769.

4. Schossig, P., Henning, H.M., Gschwander, S., Haussmann, T. Micro-encapsulated Phase Change Materials Integrated into Construction Materials Solar Energy Materials and Solar Cells 89 2005: pp. 297-306.

5. Kisssock, J.K., Hamming, J.M., Whitney, T.I., Drake, M.L. Testing and Simulation of Phase Change Wallboard for Thermal Storage in Buildings In: Proceedings of International Solar Energy Conference 1998: pp. $45-52$.

6. Omari, K.E., Guer, Y.L., Bruel, P. Analysis of MicroDispersed PCM-Composite Boards Behavior in a Building's Wall for Different Seasons Journal of Building Engineering 7 2016: pp. 361-371.

7. Silva, T., Vicente, R., Amaral, A., Figueiredo, A. Thermal Performance of a Window Shutter Containing PCM: Numerical Validation and Experimental Analysis Applied Energy 179 2016: pp. 64-84.

8. Oliver, A. Thermal Characterization of Gypsum Boards with PCM Included: Thermal Energy Storage in Buildings Through Latent Heat Energy and Buildings 48 2012: pp. $1-7$.
9. Benard, C., Gobin, D., Gutierrez, M. Experimental Results of a Latent Heat Solar Roof Used for Breeding Chickens Solar Energy 6 (4) 1981: pp. 347-354.

10. Chou, H.M., Chen, C.R., Nguyen, V.L. A New Design of Metal-Sheet Cool Roof Using PCM Energy and Buildings 57 2013: pp. $42-50$.

11. Ong, K.S. Temperature Reduction in Attic and Ceiling Via Insulation of Several Passive Roof Designs Energy Conversion and Management 52 2011: pp. 2405-2411.

12. Alawadhi, E.M., Alqallaf, H.J. Building Roof with Conical Holes Containing PCM to Reduce the Cooling Load: Numerical Study Energy Conversion and Management 52 2011: pp. $2958-2964$. https://doi.org/10.1016/j.enconman.2011.04.004

13. Mindess, S. Concrete Materials Journal of Materials Education 5 1982: pp. 983-1046.

14. Martínez-Barrera, G., Vigueras-Santiago, E., Gencel, O., Hagg Lobland, H.E. Polymer Concretes: A Description and Methods for Modification and Improvement Journal of Materials Education 33 (1-2) 2011: pp. 37-52.

15. Tao, H.S. Research for Developing Aerated Concrete by Using Fly Ash with High Calcium of Gehua Power Plant in Hongshan. Doctoral dissertation, Ph.D., Wuhan University of Technology, WuHan, 2004.

16. Alduaij, J., Alshaleh, K., Haque, M.N., Ellaithy, K. Lightweight Concrete in Hot Coastal Areas Cement and Concrete Composites 21 1999: pp. 453-458. https://doi.org/10.1016/S0958-9465(99)00035-9

17. Cabrillac, R., Florio, B., Beaucour, A.L., Dumontet, H., Ortola, S. Experimental Study of the Mechanical Anisotropy of Aerated Concretes and of the Adjustment Parameters of the Introduced Porosity Construction and Building Materials 20 2006: pp. 286-295.

18. Kearsley, E.P., Wainwright, P.J. Porosity and Permeability of Foamed Concrete Cement and Concrete Research 31 (5) 2001: pp. 805-812. https://doi.org/10.1016/S0008-8846(01)00490-2

19. Wang, X., Yu, H., Li, L., Zhao, M. Experimental Assessment on the Use of Phase Change Materials (Pcms)Bricks in The Exterior Wall of a Full-Scale Room Energy Conversion and Management 120 2016: pp. 81-89.

20. Zhou, G., Pang, M. Experimental Investigations on the Performance of a Collector-Storage Wall System Using Phase Change Materials Energy Conversion and Management 105 2015: pp. $178-88$. https://doi.org/10.1016/j.enconman.2015.07.070

21. Zwanzig, S.D., Lian, Y., Brehob, E.G. Numerical Simulation of Phase Change Material Composite Wallboard in a Multi-Layered Building Envelope Energy Conversion and Management 69 2013: pp. 27-40. https://doi.org/10.1016/j.enconman.2013.02.003

22. Silva, T., Vicente, R., Soares, N., Ferreira, V. Experimental Testing and Numerical Modelling of Masonry Wall Solution with PCM Incorporation: A Passive Construction Solution Energy and Buildings 49 2012: pp. $235-245$. 